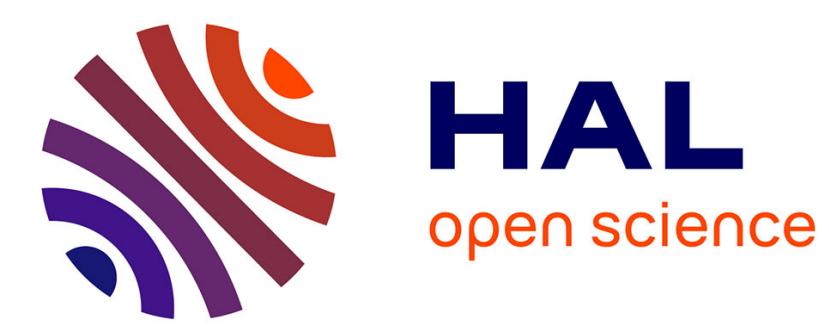

\title{
The Effect of Brand on the Impact of e-WOM on Hotels' Financial Performance
}

Elisabetta Raguseo, Claudio Vitari

\section{To cite this version:}

Elisabetta Raguseo, Claudio Vitari. The Effect of Brand on the Impact of e-WOM on Hotels' Financial Performance. International Journal of Electronic Commerce, 2017, 21 (2), pp.249 - 269. 10.1080/10864415.2016.1234287 . halshs-01656399

\section{HAL Id: halshs-01656399 \\ https://shs.hal.science/halshs-01656399}

Submitted on 14 Nov 2018

HAL is a multi-disciplinary open access archive for the deposit and dissemination of scientific research documents, whether they are published or not. The documents may come from teaching and research institutions in France or abroad, or from public or private research centers.
L'archive ouverte pluridisciplinaire HAL, est destinée au dépôt et à la diffusion de documents scientifiques de niveau recherche, publiés ou non, émanant des établissements d'enseignement et de recherche français ou étrangers, des laboratoires publics ou privés. 


\section{Cover page}

\section{Authors’ names and affiliations}

Elisabetta Raguseo

Grenoble Ecole de Management

Postal address : 12 Rue Pierre Sémard, 38000 Grenoble (France)

email: elisabetta.raguseo@grenoble-em.com

Phone : +33456806811

Claudio Vitari

Grenoble Ecole de Management

Postal address : 12 Rue Pierre Sémard, 38000 Grenoble (France)

email: claudio.vitari@grenoble-em.com

Phone : +33476706287

\section{Elisabetta Raguseo bio}

Elisabetta Raguseo is a Marie Curie research Fellow at the Business School Grenoble Ecole de Management (France). In 2012, she hold a high quality $\mathrm{PhD}$ programme in Innovation Management and Product Development attended at the three Italian Polytechnics. Her research and teaching expertise is in strategic information systems, use of advanced Information Technology (IT) to support business activities, business economics and big data. Dr. Raguseo is author of several research paper published in international journals including Information \& Management, International Journal of Technology Management, International Journal of Information Management, New Technology, Work and Employment, and International Journal of Engineering Business Management.

\section{Claudio Vitari bio}

Claudio Vitari is an Associate Professor at Grenoble Ecole de Management (Grenoble, France). His research interests include Information Systems, Strategic Management, and Ecological Economics. His publications encompass several articles in journals including Ecological Economics, Systèmes d'Information et Management, European Journal of Information Systems, Communications of the Association for Information Systems, International Journal Knowledge Management, Knowledge Management Research \& Practice, Journal of Information Technologies: Cases and Applications. Many of his articles are published in the proceedings of different international conferences. He has over 15 years' experience in teaching, research, management and consulting. Claudio Vitari is member of the endowed chair "Mindfulness, Wellbeing at work and Economic Peace”. He got his PhD from Montpellier University (Montpellier, France) and the Carlo Cattaneo University (Castellanza, Italy). He received his French accreditation to supervise research (HDR) from Montpellier University (Montpellier, France). 


\title{
The Effect of Brand on the Impact of e-WOM on Hotels' Financial
}

\section{Performance}

\begin{abstract}
Travellers increasingly consider electronic word of mouth (e-WOM) from online review platforms when making their accommodation decisions. Theory predicts that e-WOM increases sales, but little is known regarding the role that branding plays in the relation between e-WOM and hotels’ financial performance. This study relied on financial data (including Revenue per Available Room - RevPAR - and sales profitability) and 34,164 online customer reviews gathered from TripAdvisor (as a proxy for e-WOM) based on panel data from 221 hotels, including not-branded and branded chain hotels in France from 2005 to 2013. The results show that the volume of reviews has no effect on RevPAR growth for branded chain hotels and a positive effect on RevPAR growth for not-branded chain hotels. Additionally, the direct effect of the valence of online reviews and its interaction effect with the yearly and cumulative volume of online reviews on RevPAR growth and sales profitability is shown to apply to not-branded chain hotels but not to branded chain hotels. This study contributes to the e-WOM literature by revealing the role of a brand in e-WOM's impact on hotel financial performance. Based on our results, managers of branded chain hotels should know that they might find it difficult to leverage e-WOM to achieve higher RevPAR growth and greater sales profitability, as their economic advantages derive from their brand instead of e-WOM.
\end{abstract}

Keywords: e-WOM; branded chain hotels; financial performance; panel data. 


\section{Introduction}

A brand is considered a primary asset in many industries. Brands often provide the first element of differentiation among competitive offerings, and accordingly, they can be critical to the success of companies [43]. Researchers have posited that branding is particularly critical in service industries such as the hotel business [32]. In recent decades, among all the service industries, the hotel industry has embraced and accepted branding as a distinguishing component of its marketing strategy and has expressly generated extensive hotel brand segmentation [12].

Brands help hotels to identify and differentiate themselves in the minds of customers [32]. A brand symbolises the essence of customer perception of a hotel chain and embraces all the tangible and intangible attributes of the business that it refers to. Hotel guests rely on brand names to reduce the risks that are associated with staying at an unknown hotel [29]. When customers in this industry make their purchases according to their perception of a company's brand, a strong brand confers benefits on these hotels. These benefits include greater customer loyalty, increased willingness on the part of customers to pay a premium price for the brand, higher profit margins, and a more positive customer response to price changes [17].

Today, travellers rely on new sources of knowledge to reduce the risks associated with hotel choice; thus, $49 \%$ of travellers reported that travel review websites are the most useful source of information when researching and planning a trip [38]. Online review platforms have acquired increased market power and increased influence over customer purchases [40], and they have improved market transparency for travellers [2]. In this context, potential customers often seek a certain volume of recommendations in determining which product or service to purchase out of the huge selection of alternatives available online [3]. Therefore, online customer-generated content can be a valuable source of information for both travellers and hotels. 
The management literature has previously investigated the effects of electronic word-of-mouth (e-WOM) on price and sales [27], but some aspects of these effects remain unexamined. In particular, it remains unknown whether hotels must invest resources in carefully monitoring and responding to e-WOM and whether such efforts will yield different results for not-branded and branded chain hotels, i.e., hotels that share a common brand with other hotels in the same hotel chain [21]. One study has explored the variables that influence the room prices of branded chain hotels [36], but the dependent variable was room price and not different hotels' financial performance. Financial data are useful to understand the effects of different profit-generating mechanisms [28]. Furthermore, previous scholars who have investigated hotel financial performance $[23 ; 25 ; 26 ; 30 ; 35 ; 37 ; 42]$ did not focus on e-WOM and branded chain hotels. Consequently, we still do not know the extent to which e-WOM leads to different financial performance for branded chain hotels, on one hand, and not-branded chain hotels, on the other.

The contribution of the different manifestations of e-WOM - the valence and the volume of online reviews - is also partially unknown. In particular, the differing impacts of the cumulative volume of online reviews compared with the annual volume of online reviews are unclear, as are the interaction effects with the valence of online reviews. Finally, previous research has generally leveraged cross-sectional data methods. These cross-sectional methods make it arduous to consider the possible existence of lagged effects in the impact of e-WOM on hotel financial performance.

Given these knowledge gaps, this paper contributes to the existing literature in several ways. First, it examines how e-WOM affects the performance of branded compared with not-branded hotels by understanding whether a presence on online review platforms provides an additional financial advantage to branded chain hotels. Second, we propose to test the influence of branding 
on e-WOM by using the financial performance of hotels as the dependent variable. Third, this study considers different measures of e-WOM, namely, the cumulative and the annual volume of online reviews, the valence of online reviews, and their interaction effects.

Thus, the research question that we intended to answer is as follows: "To what extent does branding play a role in the impact of e-WOM on hotel financial performance?” To address this research question, we collected the panel data on 221 French hotels from TripAdvisor and the INSEAD OEE Data Services (IODS) - Altares database from over a period of nine years. Methodologically, we adopted fixed effects models with lagged variables to assess the effects of the metrics of e-WOM on the financial performance of branded and not-branded chain hotels. The findings have meaningful implications for hotel managers and allow us to understand the effects of branding on the economic returns of e-WOM and the benefits of using online review platforms.

The remainder of this paper is organised as follows. The first section of the paper reviews the literature that analyses the value of both branding and e-WOM for hotels. This literature review leads us to define the hypotheses, discussed in the subsequent section. The hypotheses offer predictions concerning the effect of branding on the returns of e-WOM and hotel financial performance. Then, the empirical analysis is shown, and the results are discussed. Then, the managerial implications are presented, and future research directions are proposed. Finally, conclusions are provided. 


\section{Literature review and hypotheses}

\section{The value of e-WOM for hotels}

The existing literature emphasises the importance of word-of-mouth (WOM) [16; 43]. In the Internet era, the value of WOM is reinforced and becomes e-WOM because individuals can electronically share their opinions and ideas in online communities that are easily accessible to other Internet users [10].

The influence of e-WOM has been studied in several industries, including the movie and book industries. In this regard, several recent studies have analysed the direct link between the number of reviews of a product and its sales [9]. For example, one study analysed the effect of consumer reviews (number and star rating) on the relative sales of books on Amazon.com [7]. The study's authors found that an increase in a book's customer rating causes an increase in sales on this site. In the movie industry, another scholar found that the number of reviews is the driver of future box office sales [27].

The influence of e-WOM can also be valuable for the hospitality industry. In the hospitality industry, e-WOM principally relates to the user-generated content that travellers post on online review platforms. These online review platforms allow users to share travel experiences based on the principle that travellers can post reviews, comments and ratings of a hotel and can even add photos [29]. Online review platforms have been gaining increasing market power in terms of influencing customer purchases [39] and in improving market transparency for travellers [2]. Travellers' e-WOM reduces information asymmetry between the hotel and the traveller, and it can be a valuable source of information for both travellers and hotels.

From a traveller's perspective, e-WOM provides them with additional information to mitigate uncertainty regarding the quality of a hotel and its fit with their needs and preferences for 
accommodations and destinations [33]. Travellers who use online review platforms can compare customer reviews and ratings for different hotels and the prices that hotels apply through several online travel agencies. A positive e-WOM signals that the hotel offers high-quality services and products and therefore, is more likely to fulfil the requirements and the expectations of the customers who reserve a room on an online channel [27]. From a hotel's perspective, hotels can monitor traveller perception of the levels of quality services offered; hotels can also eventually exploit e-WOM to improve their services and can integrate e-WOM in their strategies [27]. Thus, high ratings and good reviews from past customers can create an advantage for hoteliers because e-WOM can help hotels attract new customers [19].

Because travellers cannot evaluate a hotel before they stay there, the hotel's room purchase process is inherently risky. This risk tends to lead some customers to choose branded chain hotels. Branded chain hotels provide value added to guests by leveraging their brand and building brand loyalty [4]. A brand provides value to customers by assuring them of a defined standard of quality [29] that allows a hotel to ask for a premium price. As more customer loyalty grows, a branded hotel can capitalise more on the increasing value of its brand. Stronger brands facilitate the establishment of higher price premiums and, therefore, higher margins, less price elasticity and more rapid brand expansion [30]. One study demonstrated that a brand contributed 20-25\% of the going-concern value of a successful branded chain hotel [31].

Additional studies provide evidence that competition can be discouraged by a well-managed brand [12]. Thus, well-established brands provide hotels with a source of strategic advantage and, in turn, create financial value. The management literature has extensively demonstrated the positive correlation between a hotel with a well-established brand and its performance [18]. 
However, until now, the literature is scant about investigating the effect of e-WOM on the financial performance of branded and not-branded chain hotels. Although scholars have found a positive relation between being a branded chain hotel and financial performance [24], it is still unknown whether e-WOM has a different effect on hotels’ financial performance for branded and not-branded hotels. Based on this consideration, the following paragraphs discuss the hypotheses tested in this study.

\section{The impact of online reviews on the financial performance of branded chain hotels}

Online reviews are a manifestation of e-WOM. Previous research has emphasised that the volume of online reviews positively influences sales [1; 27]. In the tourism industry, previous research has demonstrated the positive impact of the number of reviews on the number of hotel bookings [41]. Accordingly, more travellers are aware of a hotel's offerings when there is a greater volume of reviews [6].

However, the popularity of products and services such as those provided by a branded chain hotel may influence the relation between the number of reviews and sales for two main reasons. First, branded chain hotels spend a significant amount of money on marketing campaigns to promote their well-known, high-quality services. Thus, a branded chain hotel's offering is perceived as being characterised by a certain quality. This perception, in turn, reduces traveller uncertainty concerning the purchase process. Consequently, customers in these cases will be less likely to leverage reviews in making their room choices. This process occurs because risk-handling activities are correlated positively with the amount of perceived risk [14]. This positive correlation is a reason why it is expected that consumers will conduct fewer risk-handling activities (such as reading online reviews) when booking a branded chain hotel room. 
Second, in the context of consumer purchase decisions, it has been argued that consumers feel more regret if they choose a lesser-known brand that turns out to be inferior than if they choose a well-known brand that turns out to be not better than the lesser-known option [45]. Conversely, consumers who are not interested in a branded chain hotel are more likely to search for and access more online information (such as online reviews) to shield themselves from possible regret. Therefore,

H1: The positive effect of the volume of online reviews on hotel performance is observed for notbranded chain hotels rather than for branded chain hotels.

Online customer ratings are another manifestation of e-WOM. When customers are in the position of having to engage services of uncertain quality, they often rely heavily on online customer ratings [8; 22; 44]. In the hospitality industry, the valence of online reviews represents the subjective quality dimensions of hotel services [27]. These values include, for example, the hospitality of the staff, the comfort level and cleanliness of the rooms, the quality of the facilities and services that are offered to customers (such as child care, swimming pools, conference rooms, and golf and tennis facilities) and the value that is provided for the price of the room. High customer ratings from past customers can create a price premium because they make online transactions less risky [2] and because customers are willing to pay more for a higher-rated service to be more likely to receive a higher-quality service [7]. Researchers have shown that exposure to online customer ratings increases both customer awareness of a hotel and customer consideration of it due to a significant positive relation between online customer ratings and successive sales [37]. Researchers in the tourism industry not only have found that online customer ratings impact hotel room sales [37; 42] but also have suggested that online customer ratings are more trustworthy than other sources of information [13; 18]. 
Online customer ratings appear to be particularly important for hotels without large-scale marketing campaigns and for the hotels that do not possess a brand. For these hotels, consumers may base their decisions on online customer ratings because marketing campaigns have not reached them; thus, these customers do not have sufficient information from other channels to determine the product's credibility [5].

Based on these considerations, the financial performance of not-branded chain hotels should be more impacted by the valence of online reviews. A branded chain hotel, in contrast, should not be impacted, given the previously mentioned protection that is provided by its brand. Accordingly, the valence of online reviews does not add value in terms of financial performance. Therefore, H2: The positive effect of the valence of online reviews on hotel performance is observed for notbranded chain hotels rather than for branded chain hotels.

Finally, the hotels that can attract a great number of positive online reviews with a high rating may achieve higher sales and performance. Accordingly, an interaction effect between the volume of online reviews and the valence of online reviews is expected. This interaction can occur because travellers may be more willing to trust ratings that come from a larger audience who posts a higher number of reviews. Therefore,

H3: The positive effect of the valence of online reviews strengthens the influence of the volume of online reviews on the performance of not-branded chain hotels rather than branded chain hotels.

\section{Research methodology}

\section{Data collection}

The data collection process involved a random selection of 221 French hotels from a population of 10,110 hotels and was computed by considering a confidence level of $95 \%$ and a confidence interval between $5 \%$ and $10 \%$. With our sample, we achieved a confidence interval of $6.52 \%$. 
Given the random selection, hotels were selected independently from their characteristics including whether they belong to a branded chain hotel.

The setting of branded chain hotels in France is particularly relevant to testing the research question for many reasons. First, the French hotel industry has the highest number of beds in Europe. The existence of 5 million beds [15] demonstrates the importance of this industry in France. Second, this statistic is reinforced by France's status as the second most popular destination that will be visited by international travellers in the next 24 months [40]. Third, France is a European leader when considering hotel chains that follow a brand strategy [19]. The percentage of branded chain hotels varies greatly across Europe, and France has one of the highest percentages.

For the hotels that comprise the sample, the complete financial annual report data were available from the IODS-Altares database, an online data platform that provides access to databases on finance and the economy. A panel dataset of 1,989 observations that spanned the period between 2005 and 2013 was created by including annual report information and the data that involve eWOM that were collected and presented on a meta-search website. To this end, a total of 34,164 reviews were counted, and their ratings were recorded. We focused on the meta-search website TripAdvisor because it is changing the way that tourists plan their trips. TripAdvisor allows travellers to interact and provide hotel reviews that make a traveller more knowledgeable concerning his or her purchase habits [29]. We also chose TripAdvisor because it is widely used worldwide, with 260 million unique monthly visitors and 125 million travel reviews and opinions from travellers around the world [35]. More than 100 user contributions to TripAdvisor are made every minute [38]. Specifically, to collect the data on TripAdvisor for each hotel of the sample, we followed a three-step approach. First, we searched for the hotel page on TripAdvisor. Second, 
we counted the number of online reviews that were written on TripAdvisor for the considered hotel in every year by examining all pages of the hotel on TripAdvisor. In counting the number of reviews, we took note regarding the score of every online review in every year. In this way, we collected for every hotel and for every year the number of reviews that had a score that was equal to $1,2,3,4$ or 5 . This counting provides the volume of the reviews. Third, considering these data, we compounded the average score assigned to every hotel in every year, which provides the valence of the reviews. In this way, the final database contained the number of reviews written by customers each year for each hotel and the average score of the reviews written by customers each year for each hotel. We also counted the number of reviews that received an answer from hotel manager or personnel.

\section{Measures}

Independent variable: $e-W O M$

The variable of e-WOM was operationalised by following the two elements that have been used in recent studies focusing on the tourism industry [27]. Specifically, we considered the volume and valence of online reviews [27]. To operationalise the volume of online reviews, we used two different measures: the yearly and the cumulative volume of online reviews.

Yearly volume. The first measure of the volume of online reviews is the logarithmic value of the annual number of reviews that are written in each year and for each hotel from 2005 to 2013. We chose the logarithmic form because it is a skewed distribution. Finally, this variable was standardised to make possible the evaluation of the interaction effect between valence and volume in the run models.

Cumulative volume. The second measure of the volume of online reviews is the logarithmic value of the cumulative number of reviews that were posted [7] in each year beginning in 2005. We 
also chose the logarithmic form in this case because it is a skewed variable. Finally, the variable was standardised to make possible the evaluation of the interaction effect between valence and volume in the run models.

Valence. This variable is the average online rating that is assigned by travellers [10] each year for each hotel. A traveller's rating is given on a scale of 1-5, whose value anchors are "terrible", "poor”, “average”, "very good” and "excellent”, respectively. Finally, this variable was standardised to make possible the evaluation of the interaction effect between valence and volume in the run models.

Branded chain hotel. This variable indicates whether a hotel belongs to a branded chain and was operationalised by a dummy variable [17]. If the hotel belonged to a branded chain, the dummy variable was set to 1 ; otherwise, it was set to 0 .

Dependent variable: Financial performance

Financial performance was operationalised by considering Revenue per Available Room (RevPAR) growth and sales profitability in terms of returns on sales (ROS). We chose RevPAR because it is the standard metric for measuring daily room revenue per available room in the hotel industry [34]. We chose ROS as the profitability index because it fits with this study's focus on returns from customer sales, such as in the case of travellers.

RevPAR growth. This variable is compounded by considering the annual logarithmic RevPAR growth for each hotel (i) and is computed with the following equation: RevPAR growth ${ }_{\mathrm{i}}=\mathrm{Log}$ $\left[\operatorname{RevPAR}_{\mathrm{i}}(\mathrm{t}) / \operatorname{RevPAR}_{\mathrm{i}}(\mathrm{t}-1)\right]$. We chose the logarithmic form because it is a skewed variable.

Sales profitability differential. This variable is compounded by considering the difference between the ROS for each hotel (i) in the t-th year and the ROS that was recorded in the preceding year. This variable is computed with the following equation: ROS difference ${ }_{i}=\mathrm{ROS}_{i}(\mathrm{t})$ $-\operatorname{ROS}_{i}(\mathrm{t}-1)$. 


\section{Control variables}

Number of replies. The number of replies from hotel managers to online reviews is compounded. We included this control variable because it can be a proxy for a hotel's unobservable managerial capabilities to manage and control its online visibility in general and on TripAdvisor in particular. Especially in the first years of TripAdvisor's existence, the practice of replying to user reviews was rather uncommon among hotel managers and could thus capture hotels with the rare capability of managing digital marketing and e-WOM appropriately.

ROS (t-1). This variable represents the one-year lagged value of ROS in the models where the dependent variable is the ROS difference.

Revenues (t-1). This variable represents the one-year lagged value of the logarithmic form of the sales revenue.

Years. Eight dummy variables, one for each year from 2006 to 2013, were included in the models.

\section{Panel data method}

Fixed effects regression models, which controlled for the year fixed effects, were run to estimate the relation between e-WOM and performance. In the models' specifications, the variables that measured e-WOM were lagged by one year to assess whether e-WOM in a certain year (year t-1) leads to improved performance in the subsequent year (year $\mathrm{t}$ ).

The fixed effects regression model was chosen to control for the time-invariant individual characteristics of hotels and thus avoid any bias because of the omission of relevant variables such as hotels' capabilities to manage and control their e-WOM or hotel stars. For each model, a Hausman specification test established the appropriateness of the fixed effects model over a 
random effects model because it showed that the estimates from a random effects model were not consistent.

\section{Results}

\section{Sample composition and descriptive statistics}

Table 1 presents the data concerning the sample composition. In total, $32.58 \%$ of the sample belongs to hotel groups, such as AccorHotels, with their branded chains of hotels, such as Novotel or Mercure, whereas other hotels do not belong to a branded chain. Furthermore, almost half of the sample (55.20\%) is located in cities with less than 50,000 inhabitants, and the other half (44.80\%) is located in cities with more than 50,000 inhabitants.

--- Table 1 around here ---

Table 2 shows the descriptive statistics of the variables, including the minimum and maximum values, the means and the standard deviations, and the Spearman correlation matrix. Examining the correlation coefficients, three main findings can be emphasised. First, the valence of online reviews with the yearly and cumulative number of reviews, are positively and significantly correlated. This result shows that the hotels with a higher valence of online reviews tend to attract more customers to write a review, and these customers reinforce the growth of reviews by writing opinions concerning their experiences. Second, time is correlated with both the volume and valence of online customer reviews. This finding shows that over the years, not only the number of online customer reviews but also the average rating that is expressed by travellers have increased. Third, correlations also show that RevPAR growth is positively correlated with both the valence and cumulative number of online reviews, which emphasises that higher RevPAR growth is observed when the volume and valence of online reviews are high. 
--- Table 2 around here ---

\section{Panel data analysis}

Table 3 shows the results of the eight fixed effects regression models run. One set of four models has RevPAR growth as the dependent variable, and another set of four models has the sale profitability differential as the dependent variable. In each set of the four models, two models are concerned with branded chain hotels, and the other two are concerned with not-branded chain hotels to measure the effect of branding on the investigated relations. Furthermore, in each set of models, the first two models have the yearly volume of reviews as independent variable. The other two models have the cumulative volume of reviews as independent variable. All models have a good fit indexed with R-Square values that range from $47.16 \%$ to $69.24 \%$. All models have significant F-tests with a p-value of less than $0.1 \%$.

In Hypothesis 1, we claimed that the positive effect of online reviews on hotel performance applies to not-branded chain hotels and not to branded chain hotels. The results demonstrate that the cumulative volume of reviews positively influences the RevPAR growth of not-branded chain hotels. When the yearly volume of reviews is the independent variable, the impact of the positive effect of online reviews is not significant. Specifically, Models 1 and 2 show that the volume of yearly online reviews written in t- 1 does not affect the RevPAR growth of branded either chain hotels as well as the RevPAR growth of not-branded chain hotels. Instead, Model 3 shows that the cumulative volume of reviews that refer to t- 1 does not impact the RevPAR growth of branded chain hotels, whereas according to Model 4, the cumulative volume of reviews impacts the RevPAR growth of not-branded chain hotels $(\beta=0.068$, $p$-value $<5 \%)$. Thus, we found partial support of Hypothesis 1 for the models where RevPAR growth is the dependent variable. 
In contrast, Models 5, 6, 7, and 8, with the sales profitability differential as the dependent variable, do not provide support for Hypothesis 1 . Specifically, in Models 5 and 6, the coefficient of the yearly volume of online reviews in t- 1 is not significant. Additionally, in Models 7 and 8 , the coefficient of the cumulative volume of online reviews in t-1 is not significant as well.

In Hypothesis 2, we supposed that the positive effect of the valence of online reviews on hotel performance characterises not-branded chain hotels rather than branded chain hotels. We found support for this hypothesis in all the models. We observed the relation in both cases where RevPAR growth and the sales profitability difference are dependent variables. Specifically, the coefficient of the valence of online reviews was always significant with a p-value of no more than $5 \%$ in the case of not-branded chain hotels; it was never significant in the case of branded chain hotels.

In Hypothesis 3, we hypothesised that the interaction between the online customer valence and the volume of online reviews positively affects the hotel performance of not-branded chain hotels rather than branded chain hotels. We found support for this hypothesis in the models with RevPAR growth as the dependent variable and in the models with the sales profitability differential as the dependent variable. Specifically, Models 1 and 2 show that the interaction between the online customer valence and the yearly volume of reviews in t- 1 has a nonsignificant impact on the RevPAR growth of branded chain hotels, but it has a significant and positive effect for not-branded chain hotels ( $\beta$ equal to 0.033 with p-value $<1 \%$ ). Further, Models 3 and 4 show that the interaction between the online customer valence and the cumulative volume of reviews in t-1 has a non-significant impact on the RevPAR growth of branded chain hotel, but it has a significant and positive effect for not-branded chain hotels ( $\beta$ equal to 0.033 with pvalue $<1 \%$ ). 
Models 5 and 6 show that the interaction between the online customer valence and the yearly volume of reviews in t-1 has a non-significant impact on sales profitability of branded chain hotels but a significant and positive effect on not-branded chain hotels ( $\beta$ equal to 0.851 with pvalue $<5 \%$ ). Furthermore, Models 7 and 8 show that the interaction between the online customer valence and the cumulative volume of reviews in $\mathrm{t}-1$ has a non-significant impact on the sales profitability of branded chain hotels but it has a significant and positive effect on not-branded chain hotels ( $\beta$ equal to 0.876 with $p$-value $<5 \%$ ). Overall, the coefficients of the e-WOM measures are lower in those models where RevPAR growth is the dependent variable than sales profitability differential given the logarithmic form of RevPAR growth.

Reviewing the dummy variables included as control variables in the models, the negative coefficients that refer to the yearly dummy variables show that revenue growth and the sales profitability differential decreased over time. This finding is consistent with the negative correlation coefficients of the dependent variables with the variable that refers to the year. For the models with the sales profitability differential as the dependent variable, the dummy variables are also significant for not-branded chain hotels because the diffusion of user-generated reviews on online review platforms and online travel agencies causes hotels to pay intermediation fees on the reservation transactions impacting the sales profitability of the hotel.

--- Table 3 around here ---

Table 4 summarises the hypotheses validation.

--- Table 4 around here --- 


\section{Discussion}

The objective of this study was to investigate the impact of e-WOM on the financial performance of branded chain hotels compared with not-branded chain hotels. Our results yield important and interesting insights for academic researchers and hoteliers.

The first contribution of this study to the literature concerns the evaluation of the impact of eWOM on the RevPAR of branded chain hotels. The measures of e-WOM that were considered (the yearly volume of online reviews, the cumulative volume of online reviews, the valence of online reviews and their interaction effects) impact the RevPAR growth of the not-branded chain hotels, but not the RevPAR growth of the branded chain hotels. However, when considering only the effect of the yearly volume of online reviews, its contribution is not significant with regard to the performance of hotels probably because this variable is apparently less informative in driving users' purchase decisions since it is restricted to a short period of time (one year). Conversely, the cumulative volume of reviews that cover a longer time period can be considered by customers as more informative and more useful in driving their online decisions. On TripAdvisor, it is possible to sort reviews by date. In this way, the customers that want to read TripAdvisor's reviews on a specific hotel can decide to examine the most recent reviews or all of the reviews, including the reviews written many years ago. Overall, these results indicate that customers trust both recent and older reviews.

The fact that e-WOM does not influence the revenue growth in branded chain hotels is consistent with the intrinsic features of branded chain hotels that other scholars have discussed [28; 29]. These authors have identified the importance of the brand for these hotels. The brand provides value to the customer by assuring a certain quality level. Therefore, branded chain hotels already have an advantage over not-branded chain hotels derived from the general satisfaction and loyalty 
of their customers. This satisfaction and loyalty appear to be empirically more influential than eWOM. Accordingly, e-WOM does not add value to their RevPAR growth.

The second contribution of this study to the literature concerns the effect of e-WOM on sales profitability. The results show that the volume of reviews alone (yearly and cumulative) does not influence the sales profitability of both branded chain hotels and not-branded chain hotels. Instead, the valence of online reviews leads to better sales profitability. This finding is explained by the fact that investments in quality (i.e., the valence of online reviews represents the subjective quality dimensions of hotel services) can improve a firm's profitability in two ways: through better retention of its existing customer base and through improved acquisition of new customers who are willing to pay more [20]. In these settings, when a firm is perceived to be better, it has more to gain from being perceived to be even better [11; 20].

Furthermore, the sales profitability of not-branded chain hotels is influenced by the valence of online reviews and by the interaction effect between the two measures of online reviews and the valence of online reviews. This result shows that these hotels, because of both the volume of reviews and the valence of online reviews, may exploit e-WOM more effectively than branded chain hotels. In addition, the positive impact of the interaction effect reveals that travellers more readily trust hotels with a high valence of online reviews that is associated with a higher volume of reviews than a high valence of online reviews that is associated with a smaller volume of online reviews. Through TripAdvisor, not-branded chain hotels can create greater economic value by selling their hospitality services online because branded chain hotels have already achieved economic value by leveraging their already well-known brand that identifies the quality of their services and products. This influence may occur because the posted reviews and the valence of online reviews provided by peers can positively influence travellers in choosing hotels 
and destinations that they were unaware of in the past and that sometimes appear to be anonymous. In this way, e-WOM can reduce the risk that travellers bear when they search for hotels by reducing the information asymmetries between a traveller and little-known hotels that are accessible on online review platforms. Under these conditions, not-branded chain hotels can find opportunities to create additional value online. In contrast, because they already have a high quality level of service and a well-established customer base, branded chain hotels do not see any impact that is derived from the online reviews written about them.

The results also emphasise the most influential impact of the cumulative volume of reviews on the RevPAR growth for not-branded chain hotels and the more influential impact of the valence of online reviews for these hotels on both their RevPAR growth and profitability differential. These findings mean that the greater online visibility represented by the cumulative volume of reviews enables the increase of the room sales of not-branded chain hotels that, in turn, impacts their RevPAR growth. Additionally, better online visibility, given by the valence that represents the quality of services and products offered by not-branded chain hotels, leads to an increase not only in their RevPAR growth but also in their sales profitability performance. This increase occurs probably because not-branded chain hotels are more able to leverage the quality of the services that they offer and profit more from this leverage, and because the services and products of branded chain hotels already have a high-quality reputation. Therefore, the two analysed financial performances are influenced by different attributes of online customer reviews.

Based on our results, the managers of branded chain hotels should be aware of the difficulty in leveraging e-WOM to achieve a higher RevPAR growth rate and greater sales profitability. This challenge arises because these hotels already leverage the economic advantages of owning a brand. However, branded chain hotels can use TripAdvisor and other websites that provide user- 
generated content to gather information concerning the quality of the services that are provided to maintain high brand levels, high customer service levels, and high customer satisfaction and loyalty levels and to monitor their online reputation. Not-branded chain hotels should instead be aware of the positive effect of e-WOM on their financial performance.

\section{Limitations and future research}

This study has several important and interesting extensions. First, future studies could evaluate how customers choose and select the information to consider during their online purchases and the mechanism behind their purchasing habits. Second, because TripAdvisor provides to customers the feature of declaring whether a review is useful, future research could explore the extent to which this feature is practiced by customers. If it is practiced, further studies could evaluate the impact of this feature on the financial performance that is achieved by hotels. Third, our study is limited to an analysis of the online reviews posted on a single channel, TripAdvisor, for the hotels of a single country, France. Our results may be conditioned by these choices. Accordingly, future research could replicate our analysis for a different channel and a different country. Finally, we focused on the hotel industry. Further analysis could also investigate a different industry setting.

\section{Conclusion}

This study offers insights into how e-WOM affects the performance of branded chain hotels compared to not-branded chain hotels. In particular, the influence of branding on the relationship between e-WOM and hotels' financial performance is tested by considering a variety of measures

of e-WOM, including the cumulative and yearly volumes of online reviews, the valence of online reviews, and their interaction. Fixed effects regression models reveal that the volume of reviews 
has no effect on RevPAR growth with regard to branded chain hotels while it has a positive effect with regard to not-branded chain hotels. The results also emphasise that the direct effect of the valence of online reviews and its interaction effect with the yearly and cumulative volume of online reviews on RevPAR growth and sales profitability applies to not-branded chain hotels but does not apply to branded chain hotels. Overall, this research demonstrates that not all hotels can exploit the being on websites featuring user-generated content to enhance their financial performance, since branded chain hotels do see any additional financial advantage from such content. Nevertheless, managers of branded chain hotels can still process and use the information generated on user-generated content websites for other purposes, such as monitoring their service quality and reputation or providing higher levels of customer service to guarantee consistently high standards of service to their customers.

\section{Acknowledgements}

The authors acknowledge the support of the European Community through a Marie Curie IntraEuropean Fellowship, which provided funds to one author. The authors also acknowledge the support of France’s Rhône Alps region (http://www.rhonealpes.fr/).

\section{References}

1. Amblee, N. and Bui, T. Harnessing the influence of social proof in online shopping: The effect of electronic word of mouth on sales of digital microproducts. International Journal of Electronic Commerce, 16, 2 (2011), 91-114.

2. Ba, S. and Pavlou, P.A. Evidence of the effect of trust building technology in electronic markets: Price premiums and buyer behavior. MIS Quarterly, 26, 3 (2002), 243-268.

3. Baum, D. and Spann, M. The interplay between online consumer reviews and recommender systems: an experimental analysis. International Journal of Electronic Commerce, 19, 1 (2014), 129-162.

4. Cai, L.A. and Hobson, J.S.P. Making hotel brands work in a competitive environment. Journal of Vacation Marketing, 10, 3 (2004), 197-208. 
5. Chen, Y. and Xie, J. Online consumer review: Word-of-mouth as a new element of marketing communication mix. Management Science, 54, 3 (2008), 477-491.

6. Cheung, C.M. and Thadani, D.R. The impact of electronic word-of-mouth communication: A literature analysis and integrative model. Decision Support Systems, 54, 1 (2012), 461-470.

7. Chevalier, J.A. and Mayzlin, D. The effect of word of mouth on sales: Online book reviews. Journal of Marketing Research, 43, 3 (2006), 345-354.

8. Chu, W.; Roh, M.; and Park, K. The effect of the dispersion of review ratings on evaluations of hedonic versus utilitarian products. International Journal of Electronic Commerce, 19, 2 (2015), 95-125.

9. Cui, G.; Lui, H.-K.; and Guo, X. The effect of online consumer reviews on new product sales. International Journal of Electronic Commerce, 17, 1 (2012), 39-58.

10. Dellarocas, C. The digitization of word of mouth: Promise and challenges of online feedback mechanisms. Management Science, 49, 10 (2003), 1407-1424.

11. Dellarocas, C. Strategic manipulation of internet opinion forums: Implications for consumers and firms. Management Science, 52, 10 (2006), 1577-1593.

12. Dev, C.S.; Morgan, M.S.; and Shoemaker, S. A positioning analysis of hotel brands-: Based on travel-manager perceptions. The Cornell Hotel and Restaurant Administration Quarterly, 36, 6 (1995), 48-55.

13. Dickinger, A. The trustworthiness of online channels for experience- and goal-directed search tasks. Journal of Travel Research, 504 (2011), 378-391.

14. Dowling, G.R. and Staelin, R. A model of perceived risk and intended risk-handling activity. Journal of Consumer Research, 21 (1994), 119-134.

15. Eurostat. Tourism accommodation establishment, http://ec.europa.eu/eurostat/statistics-explained/index.php/File:Tourist_accommodation_establishments,_2 013_YB15.png. (2013).

16. Fang, Y.-H. Beyond the credibility of electronic word of mouth: Exploring eWOM adoption on social networking sites from affective and curiosity perspectives. International Journal of Electronic Commerce, 18, 3 (2014), 67-102.

17. Gazzoli, G.; Gon Kim, W.; and Palakurthi, R. Online distribution strategies and competition: are the global hotel companies getting it right? International Journal of Contemporary Hospitality Management, 20, 4 (2008), 375-387.

18. Gretzel, U. and Yoo, K.H. Use and impact of online travel reviews. In O’Connor, D.P., Höpken, D.W., Gretzel, D.U. (eds). Information and Communication Technologies in Tourism 2008. Vienna: Springer, 2008, pp. 35-46.

19. Hennig-Thurau, T.; Gwinner, K.P.; and Gremler, D.D. Understanding Relationship Marketing Outcomes An Integration of Relational Benefits and Relationship Quality. Journal of Service Research, 4, 3 (2002), 230-247. 
20. Heyes, A. and Kapur, S. Angry customers, e-word-of-mouth and incentives for quality provision. Journal of Economic Behavior \& Organization, 84, 3 (2012), 813-828.

21. Holverson, S. and Revaz, F. Perceptions of European independent hoteliers: hard and soft branding choices. International Journal of Contemporary Hospitality Management, 18, 5 (2006), 398-413.

22. Huang, G.-H. and Korfiatis, N. Trying before buying: The moderating role of online reviews in trial attitude formation toward mobile applications. International Journal of Electronic Commerce, 19, 4 (2015), 77-111.

23. Jang, S.S.; Hu, C.; and Bai, B. A canonical correlation analysis of e-relationship marketing and hotel financial performance. Tourism and Hospitality Research, 6, 4 (2006), 241-250.

24. Kim, H. and Kim, W.G. The relationship between brand equity and firms' performance in luxury hotels and chain restaurants. Tourism Management, 26, 4 (2005), 549-560.

25. Lee, M.J. and Jang, S.S. Market diversification and financial performance and stability: A study of hotel companies. International Journal of Hospitality Management, 26, 2 (2007), 362-375.

26. Leonidou, L.C.; Leonidou, C.N.; Fotiadis, T.A.; and Zeriti, A. Resources and capabilities as drivers of hotel environmental marketing strategy: Implications for competitive advantage and performance. Tourism Management, 35, (2013), 94-110.

27. Liu, Y. Word of mouth for movies: Its dynamics and impact on box office revenue. Journal of marketing, 70, 3 (2006), 74-89.

28. Makadok, R. The four theories of profit and their joint effects. Journal of Management, 37, 5 (2011), 1316-1334.

29. Miguéns, J.; Baggio, R.; and Costa, C. Social media and tourism destinations: TripAdvisor case study. Advances in Tourism Research, (2008), 26-28.

30. O'neill, J.W. and Mattila, A.S. Strategic hotel development and positioning the effects of revenue drivers on profitability. Cornell Hotel and Restaurant Administration Quarterly, 47, 2 (2006), 146-154.

31. O'Neill, J.W. and Xiao, Q. The role of brand affiliation in hotel market value. Cornell Hotel and Restaurant Administration Quarterly, 47, 3 (2006), 210-223.

32. Onkvisit, S. and Shaw, J.J. Service marketing: Image, branding, and competition. Business Horizons, 32, 1 (1989), 13-18.

33. Prasad, K. and Dev, C.S. Managing hotel brand equity: A customer-centric framework for assessing performance. The Cornell Hotel and Restaurant Administration Quarterly, 41, 3 (2000), 22-4.

34. Sainaghi, R. RevPAR determinants of individual hotels: evidences from Milan. International Journal of Contemporary Hospitality Management, 23, 3 (2011), 297-311.

35. Sainaghi, R.; Phillips, P.; and Corti, V. Measuring hotel performance: Using a balanced scorecard perspectives’ approach. International Journal of Hospitality Management, 34, (2013), 150-159.

36. Silva, R. Multimarket contact, differentiation, and prices of chain hotels. Tourism Management, 48, (2015), 305-315. 
37. Tavitiyaman, P.; Qiu Zhang, H.; and Qu, H. The effect of competitive strategies and organizational structure on hotel performance. International Journal of Contemporary Hospitality Management, 24, 1 (2012), 140-159.

38. TripAdvisor. Fact sheet TripAdvisor, https://www.tripadvisor.com/PressCenter-i44-c4Fact_Sheet.html. (2014).

39. TripBarometer. TripAdvisor Announces Results of TripBarometer: World's Largest Accommodation and Traveler Survey with More than 35,000 Global Respondents, https://www.tripadvisor.it/PressCenteri5794-c1-Press_Releases.html. (2013).

40. TripBarometer. Insights on the planning and budget phase, https://www.tripadvisor.com/TripAdvisorInsights/n2208/tripbarometer-2014-insights-planning-andbudget-phase. (2014).

41. Vermeulen, I.E. and Seegers, D. Tried and tested: The impact of online hotel reviews on consumer consideration. Tourism Management, 30, 1 (2009), 123-127.

42. Wang, C.-H.; Chen, K.-Y.; and Chen, S.-C. Total quality management, market orientation and hotel performance: The moderating effects of external environmental factors. International Journal of Hospitality Management, 31, 1 (2012), 119-129.

43. Wood, L. Brands and brand equity: definition and management. Management Decision, 38, 9 (2000), 662-669.

44. Yang, J.; Kim, W.; Amblee, N.; and Jeong, J. The heterogeneous effect of WOM on product sales: why the effect of WOM valence is mixed? European Journal of Marketing, 46, 11/12 (2012), 1523-1538.

45. Zhu, F. and Zhang, X. Impact of online consumer reviews on sales: The moderating role of product and consumer characteristics. Journal of marketing, 74, 2 (2010), 133-148. 
Table 1 Sample composition

\begin{tabular}{|c|c|c|c|c|c|}
\hline \multicolumn{3}{|c|}{ Group } & \multicolumn{3}{|c|}{ Branded chain } \\
\hline Name & Number of hotels & Percentage of hotels & Name & Number of hotels & Percentage of hotels \\
\hline Logis Hotels & 20 & $27.78 \% *$ & Logis Hotels & 20 & $27.78 \% *$ \\
\hline \multirow{3}{*}{ Louvre hotels group } & \multirow{3}{*}{12} & \multirow{3}{*}{$16.67 \% *$} & Premiere Classe & 2 & $2.78 \% *$ \\
\hline & & & Campanile & 4 & $5.56 \% *$ \\
\hline & & & Kyriad & 6 & $8.33 \% *$ \\
\hline \multirow{3}{*}{ Accorhotels } & \multirow{3}{*}{11} & \multirow{3}{*}{$15.28 \% *$} & Ibis & 3 & $4.17 \% *$ \\
\hline & & & \begin{tabular}{|l|} 
Mercure \\
\end{tabular} & 4 & $5.56 \% *$ \\
\hline & & & Novotel & 4 & $5.56 \% *$ \\
\hline \multirow{3}{*}{ Seh United hotel } & \multirow{3}{*}{8} & \multirow{3}{*}{$11.11 \% *$} & P'tit Dej & 1 & $1.39 \% *$ \\
\hline & & & Relais deu silence & 1 & $1.39 \% *$ \\
\hline & & & Inter hotel & 6 & $8.33 \% *$ \\
\hline Best Western & 5 & $6.94 \% *$ & Best Western & 5 & $6.94 \% *$ \\
\hline Citotel & 3 & $4.17 \% *$ & Citotel & 3 & $4.17 \% *$ \\
\hline Chateaux et hotels collection & 3 & $4.17 \% *$ & Chateaux et hotels collection & 3 & $4.17 \% *$ \\
\hline $\begin{array}{l}\text { Other hotel groups with only } 1 \\
\text { hotel in the sample }\end{array}$ & 10 & $13.89 \% *$ & $\begin{array}{l}\text { Other hotel branded chains with only } \\
1 \text { hotel in the sample }\end{array}$ & 10 & $13.89 \% *$ \\
\hline Total & 72 & $32.58 \% * *$ & Total & 72 & $32.58 \% * *$ \\
\hline
\end{tabular}

Note: * The base for computing this percentage is the total number of hotels that belong to a branded chain. ** The base for computing this percentage is the total number of hotels in the sample. 
Table 2 Descriptives and Spearman correlations matrix

\begin{tabular}{|c|c|c|c|c|c|c|c|c|c|c|c|c|c|c|}
\hline N. & Var. & Min. & Max. & Mean & S.D. & 1 & 2 & 3 & 4 & 5 & 6 & 7 & 8 & 9 \\
\hline 1 & RevPAR growth & -2.514 & 4.308 & 0.040 & 0.322 & 1.000 & & & & & & & & \\
\hline 2 & Sales profitability differential & -32.793 & 37.904 & -0.020 & 9.298 & $0.488 * *$ & 1.000 & & & & & & & \\
\hline 3 & Branded chain hotel & 0 & 1 & 0.326 & 0.484 & -0.028 & -0.025 & 1.000 & & & & & & \\
\hline 4 & Number of replies & 0 & 435 & 4.000 & 21.554 & -0.001 & -0.016 & $0.091 * *$ & 1.000 & & & & & \\
\hline 5 & Valence of online reviews & 1 & 5 & 3.689 & 0.827 & $0.072 *$ & 0.030 & $-0.095 * *$ & $0.142 * *$ & 1.000 & & & & \\
\hline 6 & Yearly volume of online reviews & 0 & 489 & 14.059 & 34.370 & -0.015 & -0.025 & -0.005 & $0.487 * *$ & $0.205^{* *}$ & 1.000 & & & \\
\hline 7 & Revenues & 5 & 78786 & 1770.101 & 6067.87 & $0.113^{* *}$ & $0.057^{*}$ & $0.221 * *$ & $0.236^{* *}$ & 0.042 & $0.403^{* *}$ & 1.000 & & \\
\hline 8 & Year & 2005 & 2013 & 2009 & 3.452 & $-0.201 * *$ & $-0.097 * *$ & 0.032 & $0.336 * *$ & $0.080 * *$ & $0.512 * *$ & -0.037 & 1.000 & \\
\hline 9 & Cumulative volume of online reviews & 0 & 2262 & 240.623 & 116.145 & $0.068^{*}$ & -0.046 & -0.033 & $0.459 * *$ & $0.202 * *$ & $0.945^{* *}$ & $0.401 * *$ & $0.522 * *$ & 1.000 \\
\hline
\end{tabular}


Table 3 Fixed effects model results

\begin{tabular}{|c|c|c|c|c|c|c|c|c|c|}
\hline \multicolumn{2}{|l|}{ Dependent variables } & \multirow{2}{*}{$\begin{array}{c}\begin{array}{c}\text { RevPAR } \\
\text { growth }\end{array} \\
\text { Model } 1 \\
\end{array}$} & \multirow{2}{*}{$\begin{array}{c}\begin{array}{c}\text { RevPAR } \\
\text { growth }\end{array} \\
\text { Model } 2 \\
\end{array}$} & \multirow{2}{*}{$\begin{array}{c}\begin{array}{c}\text { RevPAR } \\
\text { growth }\end{array} \\
\text { Model } 3 \\
\end{array}$} & \multirow{2}{*}{$\begin{array}{c}\begin{array}{c}\text { RevPAR } \\
\text { growth }\end{array} \\
\text { Model } 4 \\
\end{array}$} & \multirow{2}{*}{$\begin{array}{c}\text { Sales } \\
\text { profitability } \\
\text { differential }\end{array}$} & \multirow{2}{*}{$\begin{array}{c}\text { Sales } \\
\text { profitability } \\
\text { differential }\end{array}$} & \multirow{2}{*}{$\begin{array}{c}\begin{array}{c}\text { Sales } \\
\text { profitability } \\
\text { differential }\end{array} \\
\text { Model } 7\end{array}$} & \multirow{2}{*}{$\begin{array}{c}\text { Sales } \\
\text { profitability } \\
\text { differential }\end{array}$} \\
\hline Model & Hypothesis & & & & & & & & \\
\hline & & \multicolumn{2}{|c|}{ Branded chain hotel } & \multicolumn{2}{|c|}{ Branded chain hotel } & \multicolumn{2}{|c|}{ Branded chain hotel } & \multicolumn{2}{|c|}{ Branded chain hotel } \\
\hline & & Yes & $\mathrm{Not}$ & Yes & $\mathrm{Not}$ & Yes & Not & Yes & Not \\
\hline \multicolumn{10}{|l|}{ Independent variables } \\
\hline Yearly volume (t-1) & H1 & 0.006 & 0.029 & & & 0.400 & -0.293 & & \\
\hline Cumulative volume (t-1) & H1 & & & -0.027 & $0.068 *$ & & & -1.724 & 0.016 \\
\hline Valence (t-1) & $\mathrm{H} 2$ & 0.013 & $0.041 * *$ & 0.005 & $0.035^{*}$ & -0.121 & $1.199 *$ & -0.225 & $1.068^{*}$ \\
\hline $\begin{array}{l}\text { Valence }(\mathrm{t}-1) \mathrm{x} \\
\text { Yearly volume (t-1) }\end{array}$ & H3 & 0.021 & $0.033^{* *}$ & & & 0.004 & $0.851^{*}$ & & \\
\hline $\begin{array}{l}\text { Valence of online reviews }(\mathrm{t}-1) \mathrm{x} \\
\text { Cumulative volume }(\mathrm{t}-1)\end{array}$ & H3 & & & 0.015 & $0.033^{* *}$ & & & -0.098 & $0.876^{*}$ \\
\hline \multicolumn{10}{|l|}{ Control variable } \\
\hline Number of replies (t-1) & & $0.002 * *$ & 0.001 & $0.002 * * *$ & 0.001 & 0.023 & 0.007 & 0.020 & 0.007 \\
\hline ROS (t-1) & & & & & & $-65.608 * * *$ & $-64.980 * * *$ & $-66.034 * * *$ & $-65.241 * * *$ \\
\hline Revenues (t-1) & & $-0.926 * * *$ & $-0.704 * * *$ & $-0.913 * * *$ & $-0.712 * * *$ & -3.075 & 0.181 & -2.273 & 0.148 \\
\hline Year 2006 & & -0.274 & -0.058 & -0.288 & -0.073 & 0.340 & $-11.280 * *$ & -0.668 & $-11.386^{* *}$ \\
\hline Year 2007 & & -0.100 & -0.023 & -0.105 & -0.056 & 4.517 & $-8.572 *$ & 4.009 & $-8.823 *$ \\
\hline Year 2008 & & -0.065 & -0.037 & -0.062 & -0.079 & 4.584 & $-10.378 * *$ & 4.501 & $-10.674 * *$ \\
\hline Year 2009 & & -0.112 & -0.091 & -0.102 & -0.147 & 2.911 & $-12.573^{* *}$ & 3.321 & $-12.872 * *$ \\
\hline Year 2010 & & -0.052 & -0.039 & -0.033 & -0.109 & 5.041 & $-11.760 * *$ & 6.028 & $-12.201^{* *}$ \\
\hline Year 2011 & & -0.031 & -0.029 & -0.001 & -0.111 & 3.634 & $-12.846^{* *}$ & 5.338 & $-13.324 * *$ \\
\hline Year 2012 & & -0.063 & -0.039 & -0.017 & -0.134 & 1.976 & $-13.597 * *$ & 4.528 & $-14.201^{* *}$ \\
\hline Year 2013 & & -0.060 & -0.105 & -0.001 & -0.211 & 0.809 & $-14.308 * *$ & 4.213 & $-15.028 * *$ \\
\hline \multicolumn{10}{|l|}{ Fit indexes } \\
\hline Constant & & $6.698 * * *$ & $4.696 * * *$ & $6.567 * * *$ & $4.828 * * *$ & 23.486 & 15.893 & 15.780 & 16.696 \\
\hline R-square & & $69.24 \%$ & $48.11 \%$ & $69.18 \%$ & $48.51 \%$ & $46.89 \%$ & $48.45 \%$ & $47.16 \%$ & $48.50 \%$ \\
\hline $\mathrm{F}$ & & $38.94 * * *$ & $10.59 * * *$ & $40.63 * * *$ & $28.18 * * *$ & $11.88 * * *$ & $23.71^{* * *}$ & $12.04 * * *$ & $23.77 * * *$ \\
\hline
\end{tabular}


Table 4 Hypotheses summary

\begin{tabular}{|l|l|l|}
\hline Hypothesis & Supported? & Findings \\
\hline $\begin{array}{l}\text { H1: The positive effect of the } \\
\text { volume of online reviews on hotel } \\
\text { performance is observed for not- } \\
\text { branded chain hotels rather than } \\
\text { for branded chain hotels. }\end{array}$ & $\begin{array}{l}\text { Partially } \\
\text { supported } \\
\text { number of reviews and RevPAR growth for the not-branded } \\
\text { chain hotels, but in the case of yearly number of reviews, it } \\
\text { is not significant. There is no significant relation between } \\
\text { the yearly or cumulative number of reviews and RevPAR } \\
\text { growth for the branded chain hotels. } \\
\text { There is no significant relation between the yearly and } \\
\text { cumulative number of reviews and the sales profitability } \\
\text { differential for the not-branded chain hotels, as well as for } \\
\text { the branded chain hotels. }\end{array}$ \\
\hline $\begin{array}{l}\text { H2: The positive effect of the } \\
\text { valence of online reviews on hotel } \\
\text { performance is observed for not- } \\
\text { branded chain hotels rather than } \\
\text { for branded chain hotels. }\end{array}$ & $\begin{array}{l}\text { Fully } \\
\text { supported } \\
\text { reviews and the sales profitability differential or RevPAR } \\
\text { growth for the not-branded chain hotels. } \\
\text { There is no significant relation between the valence of } \\
\text { online reviews and the sales profitability differential or } \\
\text { RevPAR growth for the not-branded chain hotels. }\end{array}$ \\
\hline $\begin{array}{l}\text { H3: The positive effect of the } \\
\text { valence of online reviews } \\
\text { strengthens the influence of the } \\
\text { volume of online reviews on the } \\
\text { performance of not-branded chain } \\
\text { hotels rather than branded chain } \\
\text { hotels. }\end{array}$ & $\begin{array}{l}\text { Fully } \\
\text { supported }\end{array}$ & $\begin{array}{l}\text { There is a positive interaction effect between the } \\
\text { yearly/cumulative number of reviews and the valence of } \\
\text { online reviews on RevPAR growth and the sales } \\
\text { profitability differential for the not-branded chain hotels. } \\
\text { There is any significant interaction effect between the } \\
\text { yearly/cumulative number of reviews and the valence of } \\
\text { online reviews on RevPAR growth and the sales } \\
\text { profitability differential for the branded chain hotels. }\end{array}$ \\
\hline
\end{tabular}

